\title{
Stigmatizace, morální netečnost a expertní pojmy: možné uchopení fenoménu displacement/vymístění
}

\author{
Karel Červenka
}

Displacement/vymístění je ústředím konceptem, který se prolíná celým následujícím textem v podobě jeho jednotícího principu. Hlavním popudem $\mathrm{k}$ vytvoření textu byla diskuse Displacement/vymístění na www.iske.cz. Způsob, jímž pojem displacement v následujícím textu uchopím, vychází zejména z návrhu „dívat se na displacement jako na komplexnější fenomén“ (Displacement 2003), čímž však dochází k určitému odklonu od etablovaného teoretického diskurzu, do něhož byl a je pojem displacement již zahrnut. S ohledem na tento pojmový odklon budu v textu upřednostňovat namísto anglického výrazu „displacement““ český novotvar „,vymístění“ a budu hledat nové způsoby, jak chápat sociální realitu a její fenomény tím, že se v ní budu snažit vymístění a vymíst'ující praktiky identifikovat.

Pro hledání odpovědi na otázku, jakých podob může fenomén displacement/vymístění nabýt, v jakých oblastech a jakými zpo̊soby se může objevovat a projevovat, jsem zvolil linii tématu morální indiference (morální netečnosti), jakožto tématu morálního vymístění. Právě toto téma se v textu objeví hned v několika podobách; ty se do jisté míry odrážejí v názvech jeho třech hlavních částí.

Počáteční částí textu povedu úvahu po linii Goffmanova (1986) pojetí procesů stigmatizace. Stigmatizaci chápu jako specifickou osobní, případně skupinovou situaci vymístění morální dimenze sociálních interakcí.

Druhou část věnuji zamyšlení nad tématem morální indiference ve specifické situaci modernity. Spolu s Giddensem (1991) probádám povahu moderní společnosti a vliv moderních institucí na každodenní praxi jejich aktérů. Pozornost věnuji rovněž zvláštním moderním praktikám, které Giddens (1991) označuje jako „vyloučení zkušenosti“، a jejichž projevy lze zaznamenat i na institucionální úrovni organizací, v expertních systémech.

Třetí část je vyústěním částí přecházejících. Objasním zde vztah procesů stigmatizace, „zkušenost vylučujících“ praktik a expertních systémů. Přitom se zaměřím na důsledky, které s sebou některé z expertních pojmů mohou nést. Takto se vrátím zpět k tématu morální indiference/morálního vymístění. Tentokrát však ve specificky moderním případě zdánlivě neutrálních, avšak hodnotově-zatížených, expertních pojmů.

\section{Osobní nebo skupinová situace vymístění: stigmatizace}

Jednu z možných podob, jichž situace a praktiky vymístění mohou nabýt, lze představit prostřednictvím jevu, který Goffman (1986) označuje jako stigmatizaci.

Sociálni studia. Fakulta sociálních studií Masarykovy univerzity v Brně, 2/2004. S. 215-229. ISSN 1214-813X. Stat’ vznikla za podpory grantu č. 0203-16 v rámci výzkumného záměru MSM 142300002. 
Stigmatizace spočívá ve „vy-místěni““, „pře-místěni““ a „u-místěni““ určitých symbolů, problémů nebo osob z jedněch souřadnic symbolického universa do jiných jeho souřadnic. Tyto praktiky mohou vykonávat samozřejmě pouze ti, kteří k jejich výkonu disponují dostatkem moci. To má, jak uvidíme, př́mé důsledky pro uspořádání sociální reality.

Jmenovaná manipulace se symboly může probíhat různě. Kupř́ikladu skrze pozitivní či negativní ohodnocení určitých atributů je v moci sociálního okolí postupně dospět až k odměně nebo naopak k diskreditaci dotčeného aktéra. Princip, na němž je proces stigmatizace založen, je sám o sobě neutrální povahy. ${ }^{2}$ Goffman (1986: 3) podotýká, že stigmatem může být v podstatě jakýkoliv atribut, který má pro svého nositele diskreditující účinky. V zápětí k tomu však dodává, že ne každý znak, který stigmatizuje jednoho aktéra, bude nutně stigmatizovat aktéra jiného. Takový atribut „není ani kreditovatelný ani diskreditovatelný jako věc sama o sobě“ (Goffman 1986: 3).3

$\mathrm{Z}$ tohoto důvodu může mít vlastnictví stejného atributu pro status jednoho aktéra diskreditující účinky, zatímco pro status jiného aktéra bude mít účinky neutrální či dokonce odměňující. Sociální kontext určuje, zda daný atribut bude symbolem stigmatu, neutrálním atributem či symbolem prestiže. Stigmatizace je však nejčastěji spojována se situací, jež má pro označené aktéry negativní důsledky. Tímto směrem úvahy se vydám i já v této studii.

Negativní označení okolím znamená pro aktéra často nežádoucí psychické a/nebo sociální změny jeho životní situace. Dotčený aktér pak zažívá rozmanité podoby omezení svých životních šancí; to se týká například redukce sociálních sítí či omezení přístupu k materiálním a/nebo jiným zdrojům.

Z hlediska důsledků jde při stigmatizaci o manipulaci se životními šancemi určitého aktéra, eventuelně skupiny aktérů. Je to praktika založená na manipulaci se symbolickými znaky. Její důsledky jsou však zejména pro stigmatizované aktéry právě tak skutečné jako sociální realita. Stigmatizace představuje sociální proces, jehož důsledkem je vyloučení stigmatizovaného aktéra z plného sociálního přijetí (Goffman 1986: Preface). Na obecné úrovni lze o stigmatizaci uvažovat jako o procesu, který je založen na symbolickém přesunu (vymístění) určité osoby z jedné části symbolického univerza do jiné jeho části - z té žádoucí oblasti do oblasti nežádoucí.

Symbolickému přesunu aktéra $\mathrm{z}$ jedné části univerza do jiné části a důsledkům tohoto „přesunu“ se budu věnovat v následující podkapitole.

\section{Stigmatizace jako vymístění úplného lidství}

Důležitou součástí úvahy o vymístění je téma okolností, které předcházejí nebo provázejí diskreditační praktiky. Konkrétně mám na mysli předpoklady (či spíše definice), s nimiž lidé vstupují do interakční situace a které se týkají lokalizace diskreditovaných osob v symbolickém universu.

V prrípadě, že je aktérovi jeho sociálním okolím přiděleno stigmatizující označení, je zároveň do jisté míry vnímán jako „neúplný člověk“. Tehdy stigmatizující publikum ve svých myslích aktéra redukuje z ,,celého a obyčejného člověka na člověka poskvrněného, znehodnoceného“ (Goffman 1986: 3). Právě v tomto bodě je možné povahu displacementu/vymístění v rámci stigmatizace nejlépe podchytit. Neběží tu o lecjaké vymístění, nýbrž přímo o vymístění úplného lidství. Stigma spolu s předpokladem o povaze aktéra coby „ne-úplného člově- 
ka“ v sobě skrývá potenciální důsledek v podobě vymístění nároku či práva na lidsko-právní zacházení. Jeli vymístěn „člověk“ či „lidstvi“", jsou vymístěna i jeho práva. Aktéři z publika, kteří pojmou stigma za atribut legitimně náležející označenému jedinci, s ním zároveň přijmou i jmenovaný předpoklad o ne-úplném lidství stigmatizovaného. Pro stigmatizující publikum je v takové situaci legitimní chovat se k člověku označenému stigmatem jiným způsobem, než jak status „plnohodnotné“ a tedy i plnoprávné lidské bytosti vyžaduje. Morální rozměr situace mizí, nebo je alespoň z velké části neutralizován.

Jak je vůbec možné oddělit výkon určité praktiky od jejího morálního hodnocení? Tuto otázku zodpovídá Bauman (2003: 52), když upozorňuje na to, že morální hodnocení není inherentní součástí jednání a rozhodují o něm ,jiná kritéria než ta, která řídí a utvářejí jednání jako takové“.

Ve světle Baumanova vysvětlení se stává srozumitelnější i otázka, jak může stigma, coby atribut implicitně symbolizující vymístění úplného lidství, ve svém důsledku znamenat neutralizaci morálního ohodnocení diskreditačních praktik. Prostřednictvím neutralizace morálního rozměru mohou být totiž při stigmatizaci uplatňovány všemožné způsoby diskriminace, „jejichž prostřednictvím efektivně, ačkoli často neúmyslně, redukujeme [...] životní šance“ stigmatizovaného (Goffman 1986: 5, kurzíva K. Č.).

Ona zdůrazněná „,neúmyslnost“, která nezřídka stigmatizační praktiky provází, je důležitým prvkem této studie. Téma „neúmyslnosti“ totiž upozorňuje na otázku míry vědomí (a intence), které je provozování těchto praktik věnováno.

Pro uchopení tématu „neúmyslnosti“ se nabízí Giddensův (1991: 36) koncept tzv. praktického vědomí. Praktické vědomí pro Giddense představuje součást reflexivního ovládání jednání, které je spíše „ne-uvědomované“, než-li „ne-vědomé“ povahy.

Důležitá je zde souvislost praktického vědomí s výkonem rutiny každodenní praxe. Je-li součástí každodennosti určitý způsob zacházení s vybranými kategoriemi lidí, je velmi pravděpodobné, že je spíše méně než více uvědomovaného charakteru. Projevy latentního rasizmu, sexizmu či etnocentrizmu, mohou být př́kladem pro zmíněnou neúmyslnost jednání. At’ jsou projevy těchto, často latentních, -izmů záměrné či nezáměrné povahy, mají zpravidla pliživou povahu, která je důmyslně ukryta v rutině každodennosti.

\section{"Teorie" stigmatu aneb legitimizace stigmat}

Zmíněné -izmy jsou věděním, které existenci stigmat rozmanitými způsoby legitimizuje i vysvětluje. Na jejich pozadí mají či dostávají nejrůznější stigmatizující pojmy ten „správný““ či „náležitý' význam.

Goffman zdůrazňuje, že stigmatizující pojmy (imbecil, mrzák, bastard aj.) jsou v každodenní praxi užívány jako zdroj metafor a představ, přičemž nikdo nepátrá po jejich původním významu. Goffman dále poukazuje na sklon publika ,prripisovat dané osobě celou řadu nedokonalostí na základě jedné původní a současně jí připisovat některé žádoucí" atributy. Tyto jinak žádoucí atributy však pro stigmatizovaného žádoucími nejsou, nebot' působí nadpřirozeným dojmem. Goffman uvádí jako prííklad „ک̌estý smysl“ či „,porozumění“ (Goffman 1986: 5, český překlad viz Goffman 2003: 13).

Konkrétní pojmy nabývají svého významu v kontextu obecnějšího vědění. Goffman (1986: 5) v této souvislosti připomíná tzv. ,teorie “ stigmatu, které chápe jako zvláštní formy 
ideologie. Tyto „teorie“ jsou konstruovány, udržovány a reprodukovány stigmatizujícím publikem. Často však - jakkoli paradoxně - i samotnými stigmatizovanými.

Většinu „teorií“ stigmatu nelze považovat za teorie v pravém slova smyslu. Jsou spíše kvazi-teoriemi, jejichž původ spočívá v přirozeném postoji aktérů. Ačkoli se „teorie“ stigmatu objevují většinou v podobě pre-teorií, teorií každodennosti či jiných forem laických teorií, objevují se i ve formě širších pojednání konkrétnější povahy, jejichž míra vědeckosti je různorodá. Zde mám na mysli zejména „rasově“, „pohlavně“ a obdobně zaměřené „teorie“, které činí pokusy vysvětlovat sociální procesy skrze procesy biologické. V různých sociálních a historických kontextech bývají tyto „teorie“ navázány na rozličná společensko-politická uskupení, která jimi svou existenci, stejně jako své praktiky, legitimizují a zdůvodňují nebo se jejich prostřednictvím alespoň snaží učinit sebe sama atraktivnějšími.

Racionalizační charakter některých „teorii““ stigmatu jim dodává jistou míru přesvědčivosti a poskytuje „dobré“ a „rozumné“ (zvláště „zdravě-rozumné“) důvody pro zaujatost vůči stigmatizovanému, která je založena na jiných jeho odlišnostech. Goffman $\mathrm{k}$ tomu uvádí př́ílad př́slušnosti k určité sociální třídě (Goffman 1986: 5). Obecně lze „teorie“ stigmatu chápat jako prostředek k vysvětlení představy či názoru, proč je nějaká osoba podřadná a méněcenná. Tyto „teorie“ vysvětlují „důvody“, které vedou nebo přivedly společenské okolí k přisouzení statusu „neúplného člověka“ dané osobě, tj. umožňují legitimizaci diskreditujících praktik.

V „teoriích“ stigmatu je též nezřídka zdůrazňováno přesvědčení, že daný aktér představuje nebezpečí, a zároveň poskytnuto vysvětlení, v čem tato aktérova nebezpečnost spočívá. Tehdy jde o formu zdůvodnění toho, proč je diskreditace žádoucí.

Aby vůbec mohlo docházet $\mathrm{k}$ situaci, kdy je určitý aktér či specifická skupina aktérů stigmatizována a diskreditována, je nezbytné, aby ti, kdož diskreditují, „,věděli“, že užitá praktika je žádoucí a zejména pak legitimní. Dlužno podotknout, že diskreditující aktéři nemusí nutně vědět, zda je či není daná praktika legitimní. Stačí jen nevědět, že je nelegitimní, a nebo si její nelegitimní povahu alespoň z nejrůznějších důvodů neuvědomovat či nepřipouštět.

V př́ípadě, kdy si jsou diskreditující aktéŕi vědomi toho, že jsou jejich praktiky nejen žádoucí, ale navíc legitimní, je pro ně snadné druhé lidi diskreditovat. A pokud jsou takové praktiky „normální“ a v dané komunitě či společnosti považované za samozřejmé (taken-for-granted) a rutinní a tedy ne plně uvědomované, je vstup diskreditace do těchto praktik o to hladší.

„Teorie“ stigmatu vytváŕejí kontext, který je nezbytnou podmínkou výkonu praktik vymístění úplného lidství, tedy jedné z možných podob fenoménu displacementu/vymístění. Úzký vztah „teorie“ stigmatu a praktik displacementu/vymístění představím v následující podkapitole na konkrétním př́kladu holocaustu.

\section{Holocaust - krajní príklad důsledků vymístění úplného lidství}

Důsledky stigmatizace a okolnosti fenoménu, který zde označuji jako vymístění úplného lidství, nabývají nejrůznějších podob i rozsahu. Krajní a totální podobou těchto důsledkủ je smrt dotčených aktérů. Př́ípad holocaustu v sobě tento totální důsledek i rozsah číající miliony osob spojuje. 
Právě v souvislosti s holocaustem uvažuje Bauman (2003: 18) o tzv. kategoriálních vraždách: „Muži, ženy a děti jsou vyhlazováni proto, že byli zařazeni do kategorie tvorů určených k likvidaci“. Pojmem kategoriální vraždy Bauman zdůrazňuje odlišnost aktů vraždy a genocidy. Předmětem genocidy je totiž podle něho kategorie (Bauman 2004: 303).

Pojmem kategorie Bauman (2003) poukazuje na zabstraktnění objektů genocidy. V optice rasistické ideologie jsou konkrétní lidé vnímáni pouze jako zástupci určité abstraktní skupiny osob, určité kategorie. „Pravidla obvykle dodržovaná v osobní interakci, v prvé řadě pravidla etická, neplatí tam, kde jde o zacházení s kategorií, takže ani u žádného jedince, který do této kategorie patř́ jen proto, že byl do ní zařazen." Tato abstraktizace činí z genocidy specifický způsob vraždění, při němž „se nehledí na rozdíly věku, pohlaví, osobních vlastností a charakteru. [...] Aby byla genocida možná, je nejdříve třeba osobní rozdíly smazat a tváře rozpustit v uniformní mase abstraktní kategorie.“ Nejsou tak vyhlazování konkrétní lidé židovského původu, ale abstraktní Židé, podotýká Bauman (Bauman 2003: 303).

Kategorie, do níž aktér patří a nebo patřit může, je rozpoznatelná na základě informace, kterou o něm podává jeho sociální identita. Tím, že je s lidmi zacházeno výhradně na základě jejich sociální identity, dochází $\mathrm{k}$ setření (k vymístění) jejich osobní identity, která je založena na individuálních charakteristikách konkrétního jedince. Bauman (2003: 303) zdůraznil, že v př́ípadě holocaustu nejsou důležité rozdíly věku, pohlaví, osobních vlastností či charakteru. Na důležitosti nabývá „židovstvi““ jako hlavní kategorie. V případě sexizmu je to znak „pohlaví“, na jehož základě je rozhodnuto, kdo je či není diskreditován. Atributy, které indikují specifickou sociální identitu aktéra (židovství, gender) a řadí jej tak v myslích jeho okolí mezi členy specifické - v tomto případě diskreditované - sociální skupiny, lze považovat za stigmata.

\section{Shrnutí}

V první části studie jsem popsal stigmatizaci jako jeden z možných projevů displacementu/vymístění. Ač se stigmatizace jeví jako „pouhá hra se symboly“, má své reálné důsledky. Důsledkem stigmatizace je obvykle diskreditace stigmatizovaných osob. Tato diskreditace bývá legitimizována prostřednictvím praktiky, kterou zde nazývám „vymístění úplného lidstvi". Stigmatizace může $\mathrm{v}$ krajních důsledcích vést až $\mathrm{k}$ fyzické likvidaci stigmatizovaných osob. Ve specifickém prostředí modernity je krajním př́ípadem holocaust.

\section{Předpoklady a okolnosti vymístění: morální indiference ${ }^{4}$}

\section{Morální indiference aneb vymístění morální dimenze situace}

V předchozí části byla řeč o vymístění úplného lidství. Jedná se o způsob, jehož prostřednictvím je možno z určité praktiky, resp. sociální situace, vymístit její morální rozměr. $\mathrm{V}$ důsledku se jedná o definici situace, na jejímž základě dochází $\mathrm{k}$ odlidštění, de-moralizaci, dehumanizaci, dané situace. Takto definovaná praktika se stává vůči objektu svého působení, jímž je zpravidla lidská bytost, ${ }^{5}$ „,morálně indiferentni“ a z perspektivy jednajících aktérů i morálně neproblematickou a legitimní. 
Jádro fenoménu morální indiference tkví ve specifické povaze vztahu morálního hodnocení a praktiky, na něž se toto hodnocení vztahuje. Výše v textu jsem uvedl Baumanovu (2003: 52) myšlenku, že morální ohodnocení je vưči hodnocenému jednání vnější povahy. Je na něm nezávislé. Určité jednání je tudíž možné stejně dobře morálně „naplnit“, jako „vyprázdnit“. $\mathrm{K}$ tomuto tématu se ještě vrátím, a to zejména $\mathrm{v}$ tématech „vnitřně referenčních systémů“ a tzv. „vyloučení zkušenosti“ (viz Giddens 1991).

Bylo již řečeno, že v rámci displacementu/vymístění hraje výraznou roli morální dimenze. Morální indiference, která (ve zde diskutované podobě vymístění úplného lidství) je do jisté míry charakteristická pro situace stigmatizace, se však v moderní společnosti objevuje i v jiných oblastech, a to dokonce na institucionální úrovni organizací. Př́ípadné morálně indiferentní praktiky tak nabývají mnohem koordinovanějšího a efektivnějš́ího průběhu, přičemž začínají v jistém ohledu žít svým vlastním životem nezávisle na konkrétních lidech. ${ }^{6}$ Tím se dostávám k otázce vztahu displacementu/vymístění a specifických rysů modernity.

\section{Povaha modernity a morální indiference}

Diskutovaný fenomén morální indiference je průběžným projevem a zejména pak důsledkem jevu, který Giddens (1991: 145) zmiňuje v souvislosti s modernitou a jejími specifickými rysy a který označuje jako „vypařování morálky“ (evaporation of morality). Giddens vnímá „vypařování morálky“ jako nezamýšlený důsledek obecně společenských praktik, které modernitu konstituují a reprodukují (Giddens 1991: 145).

Okolnosti zde studovaného jevu je tudíž třeba hledat v samotné povaze modernity. Giddens upozorňuje zvláště na procesy, které směřují k podřizení světa lidské nadvládě. Tyto procesy jsou charakteristické vytvářením vnitřně referenčnich systémů věděni a moci, čímž dochází k umělému uspořádávání světa. Umělého uspořádání světa je dosahováno na základě principů lidského vědění a tedy nikoli na základě vlivů, které jsou vůči lidské aktivitě vnější. Prostředí pak působí dojmem větší přehlednosti a ovladatelnosti, než je tomu u nevypočitatelné př́rody. Je organizováno do částí, jež lze reflexivně ovládat (Giddens 1991: 144). S jistou mírou nadsázky lze současný svět přirovnat k „černé skřiňce“, jejíž funkce ovládáme za pomoci uživatelsky přátelského rozhraní, interface.

Pro analýzu fenoménu morální indiference shledávám spolu s Giddensem (1991) důležitým již uvedený princip vnitřní reference. Vnitřně referenční systém lze zjednodušeně popsat jako systém, který vše, co se v jeho rámci děje, odkazuje ke svým vlastním měřítkům a nikoli $\mathrm{k}$ měřítkům, které existují mimo něj. Princip vnitřní reference spočívá na úplné redukci vnějšisch vlivu. Vnitřní reference tak zakládá specifické normy, kterými se fungování systému řídí. Vnější vlivy se snaží eliminovat.

Pro onu ,úplnou redukci vnějších vlivi̊“ zvolil Giddens metaforu „otupení drsných hran“. Redukce vnějších vlivů spočívá ve vyloučení každého chování, které není součástí mechanismů systémové reprodukce. Takové chování je učiněno diskrétním a odcizeným. Drsné hrany nežádoucího chování jsou otupeny do žádoucího tvaru (Giddens 1991: 150).

Praktiky úplné redukce vnějších vlivů jsou prostředkem, s jehož pomocí se moderní systémy vypořádávají s faktory, které jsou vučci jejich vnitřní logice vnější povahy. Vedlejším produktem či nezamýšleným důsledkem, chceme-li, těchto systémových praktik je pak to, co Giddens označuje jako „vypařování morálky“ (Giddens 1991: 145). 


\section{„Otupování drsných hran": praktiky „vyloučení zkušenosti“"}

Pojmem „vyloučení zkušenosti“ (the sequestration of experience), jímž označuje praktiku „otupování hran“, propojuje Giddens (1991) systémovou úroveň úvahy s úrovní každodenní praxe sociálních aktérů.

Formulace konceptu „vyloučení zkušenosti“ vychází z předpokladu nepostradatelnosti pocitu ontologického bezpečí pro neproblematický výkon rutiny každodenní praxe sociálními aktéry. Pocit ontologického bezpečí je charakteristický „důvěrou“ a pragmatickým postojem, který aktéři zaujímají vi̊či okolnímu světu. Tento pocit na jedné straně umožňuje výkon každodenní rutiny, na druhé straně je „samotnou rutinou primárně udržován“ (Giddens 1991: 167). Praktiky „vyloučení zkušenosti“ mají přispět ke stabilitě tohoto pocitu. „Vyloučení zkušenosti“ je totiž předpokladem pro „budování rozsáhlých oblastí relativního bezpečí v každodenním životě v podmínkách modernity“ (Giddens 1991: 167).

Lidé mohou své každodenní aktivity vykonávat rutinním způsobem až tehdy, kdy mají pocit bezpečí a jistoty a nemusí tudíž neustále vyhodnocovat podmínky výkonu těchto svých aktivit. Rutina samotná znamená vždy určitou míru „otupení“ vnějších vlivů a vyžaduje pragmatický předpoklad, že vše funguje podle očekávání. Ačkoli morální indiference není př́mou podmínkou výkonu každodenní rutiny založené na „,vyloučení zkušenosti“, lze ji považovat za nezamýšlený důsledek jejího praktikování.

To, co zde označuji za morální indiferenci, je nezamýšleným důsledkem praktik „vyloučení zkušenosti“. Zdá se totiž, že v podmínkách modernity dochází $\mathrm{k}$,potlačení skupiny základních morálních a existenciálních složek lidského života" a jejich vytlačení na vedlejší kolej (Giddens 1991: 167). Morálka a existenciální otázky již nejsou z hlediska podmínek provozování rutinní praxe považovány za důležité. Praktiky „,vyloučení zkušenosti“ odstraňují základní aspekty „životní zkušenosti, zvláště morální krize, z řádu každodenního života vybudovaného abstraktními systémy modernity“. Pocitu ontologického bezpečí je přitom dosahováno institucionalizovaným zbavováním „sociálního života základních existenciálních otázek, které před lidské bytosti kladou morální dilemata“ (Giddens 1991: 156). Podle Giddensova názoru by totiž morální dilemata mohla nabourávat pocit ontologického bezpečí, který je svou povahou velice křehký. Pokud by tyto složky „odstraněny“ nebyly, uvedené oblasti života by nepůsobily bezpečně a neproblematicky a aktéři by byli vystaveni možnosti, že budou konfrontováni s otázkami, které by provozování rutiny narušovaly nebo by je dokonce znemožňovaly.

\section{Oblasti „vyloučené ze zkušenosti“ a zprostředkovaná zkušenost}

Na první pohled by se mohlo zdát, že „,vylučování zkušenosti“ je záležitostí individuální a individuálně psychologickou. Jelikož však individuálním praktikám „vylučování zkušenosti“ předchází vylučování na systémové úrovni uspořádání společnosti, je třeba v tématu ontologického bezpečí vidět také sociální rozměr.

Podle Giddense (1991: 156) je rutina každodenního života institucionálně zbavována zkušenosti s následujícími fenomény: šílenství, kriminalita, nemoc a smrt, sexualita, príroda. V těchto prŕípadech je „vyloučení zkušenosti“ úlohou pro specifické organizace jako je psychiatrická klinika, věznice či nemocnice (Giddens 1991), které „ošetřuji“ morálně problematic- 
ká témata. Morální témata jsou v nich ukrývána spolu s lidmi, kteří jsou ,vyloučeni z účasti na konvenčních sociálních aktivitách“ (Giddens 1991: 161).

„Ostré hrany“ smrti či nemoci jsou, pokud možno, otupovány vytlačením těchto jevů do prostoru nemocnic. Stávají se technickou záležitostí. Je úkolem profesionálů, aby podle indikátorů technické povahy (fyziologické ukazatele) rozhodli, zda se aktér nachází ve stavu smrti či nikoli.? Klíčové životní zkušenosti (tedy nejen smrt) se odehrávají ve specializovaných institucích (Giddens 1991: 161). Morální rozměr smrti a nemoci mizí, zůstává technické vědění - vědění morálně indiferentního charakteru. ${ }^{8}$ Do kompetence expertů (profesionálů) se však dostávají i ostatní ze zkušenosti ,vyloučené“ oblasti.

Giddens (1991: 165) tvrdí, že „,vyloučení zkušenosti“ je specifikem moderní kultury, v níž jsou estetické a morální oblasti rozloženy rozšiřováním technického vědění. Zkušenost s těmito oblastmi života se stává zprostředkovanou skrze vědění integrované do expertních systémů. Je to právě zprostředkovaná zkušenost, která ,,podporuje vyloučení, spíše než aby ho pomáhala omezit“ (Giddens 1991: 169). Na téma zprostředkované zkušenosti aktérů s ,vylučovanými““ oblastmi Giddens podotýká, že přímý kontakt aktérů se smrtí nebo s vážnou nemocí může být velice sporadický. Ovšem díky beletristické literatuře a dokumentární prezentaci, které ,jsou plné materiálů, jež znázorňují násilí, sexualitu a smrt“", se lidé do kontaktu s těmito fenomény přeci jen dostávají a možná i ve větší míře než v před-moderních podmínkách (Giddens 1991: 198). Morálně zatížené oblasti lidského života však i nadále zůstávají př́mé zkušenosti aktérů nedostupné.

Nepřímou, zprostředkovanou zkušenost s těmito oblastmi zajišt’ují jednak profesionálové (a expertní systémy) a jednak média. Zkušenost aktérů s morálně zatíženými tématy je tedy nutně zkreslené povahy - tu dochází ke zkreslení expertním věděním, tu způsoby, jimž uvedené oblasti reprezentují média. ${ }^{9} \mathrm{Na}$ místo v minulosti vyčleněné pro autentickou zkušenost, která s sebou nese zkušenost s komplexitou daného jevu v konkrétní situaci, jsou umíst'ovány před-připravené a neproblematické (dobře „stravitelné“ či dokonce atraktivní) způsoby reprezentací morálně-zatížených zkušeností a témat, které je však zpravidla zjednodušují a idealizují.

\section{Shrnutí: Ambivalentní povaha praktik „vyloučení zkušenosti“"}

Modernita je příznačná současným výskytem protichůdných tendencí. „Ve stejném okamžiku, kdy jsou existenciální otázky potlačovány, jsou vytvářena nová pole příležitostí pro společenskou aktivitu a osobní rozvoj“ (Giddens 1991: 164). Na jedné straně je zprostředkovaná povaha zkušenosti nutným předpokladem každodenního života v moderní společnosti, na druhé straně je s ní spojena morální indiference, která činí rutinními dokonce i vylučovací procesy s negativními důsledky pro jejich objekty.

Vezměme již diskutovanou praktiku vymístění úplného lidství, která existovala - stejně jako stigmatizace - dávno před modernitou. Přesto je to právě modernita, která ji může učinit konstitutivním prvkem svých institucí a záležitostí masové povahy. Pouze v modernitě se zacházení s morálně-zatíženými tématy dostává do oblasti, která je charakteristická profesionalizací a expertizací - tj. kombinací racionální koordinace a efektivity.

Již bylo zmíněno téma holocaustu. Toto téma je případem krajních důsledků stigmatizace a zároveň důsledků, jež jsou umožněny právě specifickou povahou modernity. Bauman (2003) 
podotýká, že vraždění masového charakteru není v historii lidských společností nic neobvyklého. $\mathrm{V}$ tomto směru se nejedná o výlučnost modernity. Holocaust se však svými mnohými charakteristikami „dřívějším“ podobám genocidy vymyká. V tomto ohledu produktem modernity je: „Jako všechno, co se dělalo moderním - racionálním, plánovaným, vědecky podloženým, odborným, efektivním, koordinovaným - způsobem, i holocaust předstihl a zahanbil všechny své údajné předmoderní ekvivalenty, které ve srovnání s ním vypadají primitivně, nákladně a neefektivně“ (Bauman 2003: 140).

\section{Latentní diskreditace: expertní pojmy askriptivní povahy}

Doposud jsem se stigmatizací a modernitou zabýval z perspektivy fenoménu morálního vymístění/morální indiference jako oddělenými tématy. Následující část věnuji snaze morální vymístění/morální indiferenci probádat tak, že využiji oba tyto pojmy.

\section{Latentně a manifestně diskreditující pojmy}

Bylo řečeno, že význam jistého atributu jako stigmatu je konvenční záležitostí. Stigmatizující potenciál není inherentní vlastností atributu samotného. Jde o vlastnost, která mu byla přidělena zvenčí. Ke stigmatizaci, respektive diskreditaci, určité osoby lze v principu použít jakýkoliv atribut či symbol. Záleží pouze na významu, který mu je př́slušným sociálním prostředím přisouzen. Skutečnost je však poněkud komplikovanějšího rázu. Ne všechny pojmy, které v důsledcích diskreditují označované objekty, se jako diskreditující jeví. Jinými slovy, ne všechny pojmy, které se jeví jako neutrální, neutrálními opravdu jsou.

$\mathrm{V}$ tomto textu tedy budu rozlišovat pojmy na ty:

a) jejichž diskreditující potenciál je zjevný, manifestní - pak budu hovořit o stigmatech v pravém slova smyslu;

b) jejichž diskreditující potenciál zjevný není, je skrytý, latentní. Takové pojmy budu dále $\mathrm{v}$ textu nazývat pojmy askriptivními.

Mezi př́íklady pojmů, které působí explicitně hodnotícím - zejména pak stigmatizujícím - účinkem, lze (v př́padě prostředí dominující části společnosti) zařadit slova jako „teplouš“, „kurva“, „,negr“, „rákosník“, „fet’ák“ atd.

Ilustrací pojmů druhého typu, které jsou obdařeny hodnotícím potenciálem latentního charakteru, mohou být „zdánlivě tak neutrální biologické pojmy, jako stáŕí a pohlaví lidských organismü“, které jsou však ve „společenských souvislostech bezprostředně spojovány se selektivním přiřazováním povinností a práv, zvláště pak pozitivních a negativních statkư"“ (Šmausová 1999: 433).

Téma míry zjevnosti diskreditační povahy pojmů rozvedu v následující podkapitole.

\section{Deskriptivní a askriptivní pojmy}

Symbol není stigmatem sám o sobě. Stává se jím až poté, kdy mu takový význam byl přidělen. O symbolech stigmatu lze uvažovat podobně jako o jednání, které je chápáno jako kriminální či jinak sociálně deviantní. Šmausová (1993: 226) podotýká, že „vlast- 
nost jednání jakožto jednání ,kriminálního“ nevyplývá jednoduše z jednání samotného, nýbrž teprve z jeho ohodnocení“. Toto konstatování je možné vztáhnout i na úvahu o jiných typech sociálních deviací, než pouze na zločin, který je deviací vůči normám trestního práva. Je třeba „připustit, že definice kriminality obsahuje řadu hodnotových úsudků. Nemůže se tedy jednat o definici deskriptivní, jejíž podstatou je popis jevu nutnými a dostačujícími charakteristickými vlastnostmi bez hodnotících přívlastkư“, nýbrž o definici askriptivní (jak tento typ definic nazývá britský právní filozof H. L. Hart) (Šmausová 1993: 226).

Askriptivní definice se k objektu svého zájmu nechovají neutrálně. Obsahují totiž „nejen selektivní popis určitého jednání“ (tedy deskripci vybranými charakteristikami), „ale také jeho ohodnocení, rozhodnutí o odpovědnosti za toto jednání, jakož i rozhodnutí o tom, jaké důsledky má toto jednání mít pro jednajícího - pachatele“. Aby mohla být definice považována za deskriptivní, nesmí mít pro označovaný objekt přímé následky. To však u askriptivních definic neplatí (Šmausová 1993: 226).

\section{Askriptivní pojmy a fenomén morální indiference}

V předchozí části studie jsem vysvětlil, že v podmínkách modernity jsou některé morálně (a tedy hodnotově) zatížené oblasti lidského života vyloučeny ze zkušenosti každodenní praxe a „předány“ do kompetence expertních systémů a expertního (profesionálního) vědění.

Důsledkem této situace je to, že se smrtí, šílenstvím, nemocí či zločinem (atd.) nemohou zacházet běžní lidé. Tyto oblasti jsou svěřeny do péče odborníků, expertů, kteří jsou zaštítěni abstraktními systémy moci a vědění. Tyto jsou, jak se předpokládá, s otázkou morálního rozměru objektů svého zájmu takříkajíc vyrovnány. To je nejspíše i důvod existence etických kodexů $\mathrm{v}$ př́padě profesí relevantních $\mathrm{v}$ uvedených oblastech.

Svou pozornost nyní obrátím zejména na pojmy, které mají původ v expertním vědění a jsou (proto) obecně vnímány (často nejen laiky, nýbrž i mnohými ze samotných expertů) jako popisné, deskriptivní. Ne vždy je však možné tyto pojmy za deskriptivní považovat. V některých př́ípadech, a jde zejména o oblasti označené Giddensem (1991) jako „vyloučené ze zkušenosti“, jsou tyto pojmy a definice spíše povahy askriptivní než deskriptivní. Morální kontext takových pojmů (respektive objektů jimi označovaných) jako by př́mo sváděl $\mathrm{k}$ tomu, aby se $\mathrm{v}$ nich nějakým způsobem morální povaha objektů jimi označovaných objevila. ${ }^{10}$

Hlavní rozdíl mezi deskriptivními a askriptivními pojmy spočívá tedy v jejich odlišném vztahu viči označovaným objektům. Askriptivní pojmy/definice, na rozdíl od pojmů/definic deskriptivních, nejsou vůči objektům svého zájmu neutrální. Nejsou tedy tím, co se o nich implicitně předpokládá. Nesou s sebou pro označované objekty určité následky. To je důvodem, proč zde formulovanou otázku povahy expertních pojmů shledávám závažnou.

Jelikož s sebou askriptivní definice nesou ohodnocení objektu, jehož se týkají, jsou v tomto ohledu podobné ,stigma“ pojmům. Mohou být tudíž využity k praktikám, jejichž důsledkem je neutralizace morálního rozměru situace, tedy $\mathrm{k}$ tomu, aby byla $\mathrm{z}$ původně morálně naplněné situace učiněna situace, jež je vůči objektu dané praktiky morálně indiferentní povahy. 


\section{Askriptivní pojmy a definice situace}

V perspektivě označované jako „labeling approach“11 lze askriptivní definice, stejně jako stigma pojmy, vnímat jako „značky“, ,,etikety“ („labely“), které mají pro své nositele zpravidla negativní účinky. Představují zvláštní formy definic, které se ve svých důsledcích stávají reálnými, dovolím-li si parafrázovat Thomasův teorém. Pojmem askriptivních definic tak mohu doplnit pojem stigma, nebot' v obou př́padech jde o jistou formu označení ("label“) se specifickými (zpravidla diskreditujícími) účinky pro označovaný objekt (osobu, jednání).

Expertní pojmy jsou aktéry obvykle vnímány jako deskriptivní a hodnotově neutrální. Velice často se však dotýkají oblastí vyloučených z jejich běžné zkušenosti. Aktérům pak nezbývá než této „popisné“ a „hodnotově neutrální““ povaze expertních pojmů důvěřovat.

Expertní pojmy se jakožto definice stávají reálnými ve svých důsledcích. Svou hodnotově zatíženou povahou ovlivňují (strukturu) jednání aktérů bezprostředněji, než jak by je ovlivňovaly v podobě čistě deskriptivních pojmů. Jelikož jde zpravidla o pojmy z morálně-zatížených oblastí (zločin, sexualita, nemoc apod.), je tato latentní hodnotová zatíženost pro označené subjekty mnohem závažnějšího charakteru.

Askriptivní pojmy v sobě nesou nejen popis vybraných aspektů objektu, ale také informaci o odpovědnosti a důsledcích jednání pro jednajícího (Šmausová 1993: 226). Nemusí jít pouze o jednání označované jako kriminální, stačí, že je vnímané jako „nějak“ odlišné, deviantní (ve velmi širokém slova smyslu). Z tohoto hlediska považuji expertní pojmy, jež lze za askriptivní označit, za návody či recepty, jak s příslušnými objekty (zejména s lidmi) zacházet.

Šmausová uvažuje o problematické povaze způsobu, jímž etiologická kriminologie studuje kriminalitu. Píše, že etiologická kriminologie je „odsouzena k tomu, aby přebírala hodnotová kritéria praktiků - soudců, jako jsou zmíněné negativní vlastnosti obžalovaných, a místo aby je správně rozeznala a definovala jako vlastnosti, které vedly k odsouzení, považuje je za příčiny kriminality“ (Šmausová 1993: 226-227). K př́padům, kdy věda přebírá hodnotová kritéria praktiků nedochází jen v etiologické kriminologii, nýbrž i v jiných disciplínách. Př́́klady lze objevit v sociologii, psychologii či ve speciální pedagogice. Pokud se v dané vědě ujme prosazení uvedeného postupu, nejde o kritickou analýzu, nýbrž pouze o systematizaci poznatků na abstraktní úrovni.

Pokusím se nyní o konkrétní úvahu o vztahu profesionálů - v tomto př́ípadě praktiků v oborech a oblastech práce s mládeží (učitelé, kurátoři, vychovatelé, etopedi a další) - k diskutovaným pojmům. Tito praktikové většinou nezkoumají užívané pojmy jako takové. Spíše s nimi manipulují a na jejich základě interpretují realitu a definují situace, v nichž hodlají intervenovat do života druhých lidí (klientů, dětí). Vezmu-li za prríklad pedagogickou a speciálně pedagogickou odbornou literaturu, či dokonce dokumenty, které praktikové těchto oborů vytvářejí (hodnotící zprávy na vychovávané jedince), lze zde zaznamenat mnohé pojmy, které je možno považovat za askriptivní. V uvedených zdrojích se vyskytují např́iklad následující pojmy: problémová mládež, nepřizpůsobiví občané, obtížně vychovatelná mládež, riziková mládež, osoby s poruchami chování, nevhodné sociální chování, nezdravé sociální prostředí, závadná parta atd.

Každý z právě uvedených pojmů zavádí pozornost publika k vybraným negativně hodnoceným charakteristikám označených objektů. Takový „popis“ se omezuje pouze na ty aspekty 
vlastností a jednání označených aktérů, které jsou nositeli těchto negativních hodnot. Zároveň jsou přehlíženy vlastnosti, které mají hodnocení jednici společné s ,průměrnými“ členy společnosti. ${ }^{12}$ Výsledkem je nevyvážený, a proto zkreslený obraz vybrané části sociální reality.

\section{Významový posunů pojmů: od askripce k deskripci}

Askriptivní povahu pojmů i jejich deskriptivně orientovanou proměnu ve společenských diskurzech doložím na dvou příkladech.

V prvním př́padě jde o pojem „homosexualita“, který v současné psychiatrii označuje „méně častý typ sexuální orientace“. ${ }^{13}$ Nebylo tomu tak vždy. Procházka (viz http:// www.one4one.cz) uvádí, že teprve v roce 1973 byla Americkou psychiatrickou asociací vyřazena homosexualita ze seznamu nemocí. Celosvětově k tomu však došlo až v 10. Mezinárodní klasifikaci nemocí z roku 1992. Do té doby byla „homosexualita“ považována za duševní poruchu, tedy za nemoc.

Vliv redefinice zmíněné sociální kategorie na sociální uspořádání společnosti je poměrně značný. Jen těžko by bylo možné prosazovat zákon o registrovaném partnerství homosexuálně orientovaných párů, kdyby homosexualita byla považována za „poruchu sexuální orientace“, resp. za nemoc. Nejinak je tomu s dopadem na vzorce chování druhých vůči homosexuálně orientovaným osobám; nemluvě o dopadu na chování a sebe-pojetí těchto osob.

Druhý př́iklad je z oblasti speciální pedagogiky. Osobám, zpravidla dětem, které měly potíže se čtením, psaním a učením vůbec, ještě donedávna přináleželo označení „,děti/žáci s poruchami učeni'، ${ }^{14} \mathrm{~V}$ současnosti - často bývá udáván vliv amerického akademického prostředí - je zřjejmá snaha užívat pojem poněkud odlišný: ,dítě/žák se specifickými vzdělávacími potřebami““15 (Vítková 1998: 19). Hodnotový posun od „poruchy“ ke „specifické potřebě“ je výrazný. Tento pojmově definiční posun lze vysvětlit tím, co uvádí Vítková (1998: 19): „Základním východiskem je nerozlišování dětí na handicapované a nehandicapované a změna v zaměření na dítě v celé šíři jeho osobnosti a sociálních vztahů, nikoli se zřetelem pouze na jeho postižení،.

Oba uvedené příklady významových posunů v pojmech od askripce k deskripci uzavírají část textu, kterou jsem věnoval fenoménu displacementu/vymístění v jeho souvislostech s tzv. morální indiferencí a stigmatizací.

\section{Závěr}

V předkládané studii jsem si kladl za cíl uchopit displacement/vymístění jako komplexnější jev, který lze objevit v mnohých oblastech společenského života. Jako morální vymístění jsem ho uchopil v tématu morální indiference (morální netečnosti). Téma morální indiference se pak v textu objevilo v několika podobách.

Goffmanovo (1986) pojetí stigmatizace jsem vzal za nosnou myšlenku první části textu. Stigmatizaci jsem pojal jako specifickou osobní, př́ípadně skupinovou, situaci vymístění morální dimenze. Zaměřil jsem se konkrétně na praktiky vymístění úplného lidství. Tím jsem displacement/ /vymístění popsal coby způsob či praktiku, jež v důsledku vede k označení osob, na něž je zaměřena, za legitimní objekty diskreditace. Jako krajní př́iklad těchto praktik jsem uvedl holocaust. 
Ve druhé části studie jsem displacement/vymístění promítl do specifických okolností modernity. Zdůraznil jsem přitom morálně indiferentní rozměr tohoto jevu. Inspirován Giddensem (1991), uvažoval jsem o povaze moderní společnosti a o vlivu moderních institucí na každodenní praxi běžných aktérů. Morální indiferenci jsem tak uchopil jako nezamýšlený důsledek specifického způsobu, jímž je modernita uspořádána a uspořádávána. Věnoval jsem se i specificky moderním praktikám, které Giddens (tamtéž) označuje jako ,vyloučení zkušenosti“. Toto „vyloučeni““ (chceme-li vymístění) zkušenosti s určitými oblastmi lidské zkušenosti z každodenní praxe s sebou nese dalekosáhlé důsledky pro sociální aktéry. „Vyloučené“ oblasti se dostávají do kompetence expertních systémů, což z původně „přímé“ zkušenosti (jež byla takto „vyloučena“ či ,vymístěna“) činí zkušenost zprostředkovanou skrze experty a expertní vědění.

V závěrečné třetí části textu jsem s ohledem na specifické okolnosti modernity propojil témata morální indiference a stigmatizace. Učinil jsem tak skrze optiku konceptu askriptivních definic. Zároveň jsem zdo̊raznil důsledky, které s sebou mohou nést některé z expertních pojmů. Úvahu jsem založil na Thomasově teorému - myšlence, na níž stojí tzv. „labeling approach“. Zdánlivě neutrální expertní pojmy jsem označil za návody či recepty, jejichž prostřednictvím aktéři definují situace a které se tímto zpơsobem stávají reálnými ve svých důsledcích. Pojmy s výrazným definičním efektem, které v sobě nesou hodnocení označovaného objektu, jsem spolu s Hartem (dle Šmausová 1993) nazval askriptivními pojmy/definicemi. Pojmy této povahy mohou mít důsledky podobné důsledkům stigmat. Neutralizují totiž morální povahu objektů svého působení, které se tak stanou legitimními cíli diskreditačních praktik. Tím jsem se vrátil zpět k tématu morální indiference/morálního vymístění. Tentokrát však ve specificky moderním př́padě zdánlivě neutrálních, avšak hodnotově zatížených, expertních pojmů. Uvedl jsem, že tato situace může vést k nezáměrné diskreditaci (podobně jako k tomu dochází v př́ípadě stigmatizace), navíc však s potenciálem důsledků moderně-organizačních - tedy formálních, racionálních, efektivních a koordinovaných - aktivit.

Prostřednictvím pojmu displacement/vymístění, respektive morální vymístění, jsem tak tematizoval potenciál skryté a jemné manipulace, který je obsažen v mnohých, zdánlivě hodnotově-neutrálních a „,̌istě vědeckých“ pojmech. Důsledkem jejich (zne)užití může být záměrná, př́ípadně nezáměrná diskreditace osob, které byly těmito pojmy označeny. Na zvolených tématech jsem se pokusil poukázat na významnou roli, kterou v životě a činech sociálně-vědních badatelů i odborníků v praxi zaujímá neustálá kritická reflexe „,b̌žných“ a „rutinních“ aktivit (a pojmů) vyplňujících jejich i naši každodennost.

\section{Poznámky}

Název této části je reakcí na otázku „Jak dochází k situaci, osobní či skupinové, která je pojmenovatelná, jako displacement?“ z kapitoly diskuse o Displacementu/Vymístění „Jak se semináře zúčastnit? aneb pravidla hry“ (ISKE 2003).

2 Což také může být důvodem existence latentních forem diskreditace, jak později objasním.

3 Připomeňme základní teze tzv. labeling approach (etiketizační teorie), kde deviace není chápána jako inherentní, tedy nedílná vlastnost určitého činu či osoby; je považována za vlastnost danému činu přisouzenou jeho společenským okolím (viz např́ílad Becker 1966). S touto teoretickou perspektivou bývá spojován i Goffman. 
$4 \quad$ Název této části je reakcí na otázku „Jaké jsou předpoklady pojmenování a praktiky, které vedou k vymístění určitých osob, určitých problémů, symbolů?“" z kapitoly diskuse o Displacementu/Vymístění „Jak se semináře zúčastnit? aneb pravidla hry“ (ISKE 2003).

$5 \quad$ Nemusí jít jen o lidské bytosti. Lidé, kteří protestují proti pokusům na zviřatech, vnímají situaci pokusů jinak než ti, kteří tyto pokusy schvalují.

6 Srovnej s fenoménem ,zvěcněni““ (reifikace).

7 Před podobným problémem stáli porodníci, když měli určit bod v čase, kdy dítě ještě není narozené a kdy již narozené je. Šlo o situaci jakési soutěže o první dítě roku 2000.

8 Jak ukáži dále, ani to není zcela pravda - viz askriptivní definice.

9 Viz též Baudrillardův koncept „hyperreality“.

10 Konfliktualista by nejspíše poznamenal, že latentním cílem existence askriptivních pojmů je reprodukce př́slušného hodnotového řádu.

11 Labeling approach je u nás znám spíše jako tzv. etiketizační teorie. $\mathrm{K}$ jeho hlavním stoupencům patří Howard S. Becker, Edwin M. Lemert, Edwin M. Schur, Kai T. Erikson, a další.

12 Za tento postřeh, stejně jako za mnoho dalších připomínek a kritických poznámek k textu, srdečně děkuji prof. Šmausové.

13 V 10. revizi Mezinárodni klasifikace nemoci: Duševní poruchy a poruchy chování z roku 1992 je v souvislosti s homosexuálním sexuálním vývojem a orientací uvedeno v poznámce toto: „Sexuální orientace sama o sobě nemá být považována za poruchu“" (194).

14 Toto označení je však v praxi stále hojně využíváno.

15 Anglický a německý ekvivalent tohoto pojmu je „,special educational needs“, „,sonderpaedagogischer Foerderbedarf" (Vítková 1998)

\section{Literatura}

10. revize Mezinárodni klasifikace nemoci: Duševní poruchy a poruchy chování. 1992. Ženeva/Praha: Světová zdravotnická organizace/Psychiatrické centrum.

Bauman, Z. 2003. Modernita a holocaust. Praha: Sociologické nakladatelství.

Becker, H. 1966. Outsiders: Studies in the Sociology of Deviance. New York: Free Press.

Displacement. 2003 . (CD-ROM) ISKE, FSS MU Brno.

Giddens, A. 1991. Modernity and Self-identity. Self and Society in the Late Modern Age. Cambridge: Polity Press.

Giddens, A. 1998. Důsledky modernity. Praha: Sociologické nakladatelství.

Goffman, E. 1986. Stigma: Notes on the Management of Spoiled Identity. New York: Simon \& Schuster, Inc.

Goffman, E. 2003. Stigma. Poznámky o způsobech zvládání narušené identity. Praha: Sociologické nakladatelství.

Jak se semináře zúčastnit? aneb pravidla hry [cit. 5. 1. 2003]. ISKE: FSS MU Brno [On-line dokument] dostupný z: http://www.iske.cz/Jak.htm

Procházka, I. „Metodologická kritika tzv. léčení homosexuality.“ In: One4One: Dopis MŠMT [cit. 2. 9. 2004]. [On-line dokument] dostupný z: http://one4one.server4you.cz/dopis msmt.php

Šmausová, G. 1993. „Kritická kriminologie.“ Kriminalistika, 3: 225-235.

Šmausová, G. 1999. „,Rasa“ jako rasistická konstrukce.“ Sociologický časopis, 35 (4): 433-446. 
Vítková, M. 1998. „Vytváření rámcových podmínek pro integrativní výchovu a vzdělávání dětí a žáků se specifickými vzdělávacími potřebami.“ In M. Vítková a kol. Integrativní speciální pedagogika. Brno: Paido, s. 19-26.

\section{Autor}

Karel Červenka je interním doktorandem na Katedře sociologie Fakulty sociálních studií Masarykovy univerzity v Brně. Ve své doktorské práci se zabývá tématem sociální konstrukce reality „problémové“ mládeže. O problematiku sociálních deviací se zajímá v teorii i praxi - o „problémové“ mládeži nejen píše, ale také s ní pracuje. Kontaktní e-mail: charel@mail.muni.cz 